\title{
Membangun Website Menggunakan Framework CodeIgniter di STMIK YMI Tegal
}

\author{
Nadya Safitri ${ }^{*}$, Mardi Yudhi Putra ${ }^{1}$, Rita Wahyuni Arifin ${ }^{2}$, Rayhan Wahyudin Ratu Lolly ${ }^{1}$, \\ Ahmad Safei ${ }^{1}$
}

${ }^{1}$ Rekayasa Perangkat Lunak, Universitas Bina Insani, Jl. Siliwangi No.6, Bekasi, Jawa Barat, Indonesia, 17114

${ }^{2}$ Manajemen Informatika, Universitas Bina Insani, Jl. Siliwangi No.6, Bekasi, Jawa Barat, Indonesia, 17114

*Email koresponden: nadyasafitri@binainsani.ac.id

\section{ARTICLE INFO \\ Article history \\ Kata kunci: \\ CodeIgniter; \\ Framework; \\ Pelatihan; \\ Website; \\ YMI;}

Received: 17 Agt 2021

Accepted: 18 Nov 2021

Published: 31 Des 2021

\section{A B S T R A K}

Background: Perkembangan website pada berbagai bidang saat ini semakin meningkat, salah satu alasannya adalah dapat mempermudah pengaksesan informasi yang diperlukan tanpa ada batasan ruang dan waktu serta ada kemudahan dalam pengelolaannya. Berdasarkan perkembangan kebutuhan yang semakin meningkat, maka semakin meningkat pula kebutuhan tenaga pengembangan website. Sebagai salah satu bentuk pengabdian kepada masyarakat Universitas Bina Insani berkomitmen untuk meningkatkan skill masyarakat khususnya mahasiswa sebagai tenaga ahli dengan memberikan pengajaran dan pelatihan. Pelatihan ini bertujuan untuk meningkatkan penguasaan dan kemampuan mahasiswa dalam membangun sebuah website dengan pemanfaatan framework khususnya CodeIgniter. Metode: STMIK YMI Tegal merupakan salah satu mitra yang bekerja sama pada pelatihan ini dengan jumlah peserta 62 (enam puluh dua) peserta. Metode pelaksanaan pelatihan menggunakan metode daring dengan proses pembelajaran sinkron (Sychrounus). Pelatihan ini dilakukan dengan memberikan materi dan demonstrasi kepada peserta dalam penggunaan website menggunakan framework CodeIgniter dengan dukungan media online berupa zoom, youtube dan juga link google drive. Hasil: Hasil dari pengabdian yang dilakukan dapat dilihat dari seberapa besar tingkat penerimaan mahasiswa pada materi yang diberikan. Berdasarkan hasil umpan balik yang diberikan, materi yang disampaikan oleh narasumber mendapatkan respon baik sekali dengan nilai $62,9 \%$ dan kesesuaian materi dengan kebutuhan mahasiswa mendapatkan respon baik sekali dengan nilai 53,2\%. Keberlanjutan dari kegiatan ini diharapkan adanya pelatihan dengan tingkat lanjut. Kesimpulan: Berdasarkan hasil pelaksanaan pelatihan ini, pelatihan ini dapat memberikan manfaat serta penguasaan peserta dalam proses pembangunan sebuah website khususnya dengan menggunakan framework codeigniter yang saat ini banyak dibutuhkan oleh dunia industri.

\section{A B S T R A C T}

Background: The development of websites in various fields is increasing. One of the reasons is that it can facilitate access to the information needed without any limitations of space and time, and there is the ease in its management. This training is expected to increase the mastery and ability of students in building a website by using a framework, especially CodeIgniter. STMIK YMI Tegal is one of the partners who work together on this training with 62 (sixty-two) participants. This training is carried out by providing materials and demonstrations to participants in using the website using the CodeIgniter framework with the support of online media in the form of zoom, youtube, and google drive links. The training results carried out can be seen from the level of student acceptance of the material provided. This training received feedback, including the material presented by the resource persons, received a very good response with a score of $62.9 \%$, and the suitability of the material to the needs of students received a very good response with a value of $53.2 \%$. The sustainability of this activity is expected to have advanced training. Based on the results of this training, this training can provide benefits and mastery of participants in building a website, especially using the 
codeIgniter framework currently needed by the industrial world.

(C) 2021 by authors. Lisensi Jurnal Solma, UHAMKA, Jakarta. Artikel ini bersifat open access yang didistribusikan di bawah syarat dan ketentuan Creative Commons Attribution (CC-BY) license.

\section{PENDAHULUAN}

STMIK YMI Tegal merupakan salah satu penyelenggara pendidikan dibawah naungan Yayasan Manajemen Indonesia yang berdiri pada tahuan 2003. STMIK YMI Tegal terdiri dari 2 (dua) program studi jenjang sarjana yaitu Sistem Informasi dan Teknik Informatika (Surorejo \& Azizah, 2015). Dimana kedua program studi tersebut diharapkan berkontribusi terhadap perkembangan teknologi informasi khususnya pada bidang web development. Namun saat ini masih terjadi gap antara materi perkuliahan dengan kebutuhan dunia industri, maka dari itu dibutuhkan sebuah penambahan kemampuan dan wawasan mahasiswa, khususnya dibidang tersebut. Salah satu solusi yang dapat dilakukan yaitu adanya sharing knowledge melalui kegiatan pengabdian kepada masyarakat.

Website merupakan kumpulan dokumen yang sangat banyak yang berada pada komputer server (web server) (Mubarok \& Afifah, 2020). Seiring dengan makin berkembangnya penggunaan internet, maka perkembangan website pun menjadi salah satu kesempatan yang banyak dimanfaatkan baik organisasi maupun instansi untuk memasarkan dan mengenalkan kepada publik, dengan harapan untuk mempermudah publik dalam pengaksesan segala bentuk informasi yang disediakan oleh pengelola website tanpa adanya batasan ruang dan waktu. Website yang terdiri dari kumpulan-kumpulan halaman situs yang yang ditulis dalam format HTML (Trimarsiah \& Arafat, 2017). Dimana perkembangan website saat ini dapat dikerjakan dengan waktu yang relatif lebih cepat. Hal ini karena terdapat tool berupa framework yang dapat digunakan oleh seorang web develompment.

Framework adalah suatu kerangka kerja atau kumpulan script yang dapat membantu pengembangan sebuah aplikasi dalam menangani berbagai masalah pemrograman (Rosmala et al., 2011). Definisi lain menyebutkan framework adalah kumpulan dari fungsi-fungsi atau prosedur-prosedur serta clas-clas untuk tujuan tertentu sehingga bisa mempermudah dan mempercepat pembuatan website tanpa harus membuat fungsi atau clas dari awal (Putra \& Mualim, 2017). Terdapat banyak framework yang dapat digunakan salah satunya adalah CodeIgniter. CodeIgniter merupakan sebuah framework yang dibuat dengan mengunakan bahasa PHP, yang dapat digunakan untuk membuat website secara cepat (Tyowati \& Irawan, 2017). Framework ini banyak digunakan karena merupakan salah satu framework open source yang banyak dikembangkan oleh komunitas sehingga akan cukup mudah dipelajari serta salah satu framework PHP yang kuat dan sedikit bug (Destiningrum \& Adrian, 2017). Selain itu framework ini juga sudah menggunakan konsep MVC (Models-View-Controller) yang dapat mempermudah pengelolaan sebuah website (Afuan, 2010).

Berdasarkan latar belakang yang telah dijelaskan maka tujuan dari kegiatan Pengadian kepada Masyarakat ini adalah memberikan pelatihan bagaimana cara membangun website menggunakan framework codeigniter kepada mahasiswa STMIK YMI Tegal. 


\section{MASALAH}

Masalah utama yang saat ini terjadi yaitu masih terjadi gap antara materi perkuliahan dengan kebutuhan dunia industri, maka dari itu dibutuhkan sebuah penambahan kemampuan dan wawasan mahasiswa, maka mahasiswa STMIK YMI Tegal perlu meningkatkan keahlian dan kemampuan dalam pengembangan website dengan berbagai macam jenis framework, salah satunya yaitu CodeIgniter. Dengan harapan dapat meningkatkan skill yang dimiliki oleh mahasiswa. Oleh karena itu, STMIK YMI Tegal dan Universitas Bina Insani melakukam kerjasama dengan bentuk implementasi melaksanakan sebuah pelatihan kepada STMIK YMI Tegal dalam meningkatkan kemampuan dan wawasan mahasiswanya.

Pengabdian kepada masyarakat (PkM) merupakan kegiatan yang dilakukan oleh sivitas akademika dengan memanfaatkan IPTEK untuk kesejatheraan dan kemajuan masyarakat (Retnoningsih et al., 2020). Kegiatan PkM Membangun Website Menggunakan Framework CodeIgniter pada STMIK YMI Tegal merupakan salah satu bentuk kegiatan yang dilakukan oleh Universitas Bina Insani untuk meningkatkan penguasaan dan kemampuan mahasiswa dengan harapan : 1) Memahami konsep dasar dari codeigniter, 2) Memahami penerapan Codelgniter, 3) Langkah-langkah penerapan CodeIgniter, 4) Pemahaman konsep MVC, serta 5) Membangun website sederhana dengan menggunakan framework codeigniter.

\section{METODE PELAKSANAAN}

Pengabdian kepada Masyarakat yang dilakukan oleh Universitas Bina Insani dikemas dengan mengadakan pelatihan dengan memanfaatkan media online yang diadakan selama kurang lebih 2 (dua) jam. Pelatihan yang dilakukan merupakan kegitan yang bermaksud mengembangkan keterampilan dan pengetahuan para peserta khususnya dalam bidang pengembangan website (Permatasari \& Hardiyan, 2018). Maka dari itu ditentukan sasaran utama pada pelatihan ini adalah mahasiswa semester 3 (tiga) \& 4 (empat) dari Program Studi Teknik Informatika dan Sistem Informasi, STMIK YMI Tegal. Hal ini dikarenakan agar peserta telah mengetahui dasar-dasar mengenai website dari perkuliahan sebelumnya sehingga akan mempermudah dalam pemahaman materi pelatihan. Berikut ini gambar yang menjelaskan metode pelaksanaan PkM.

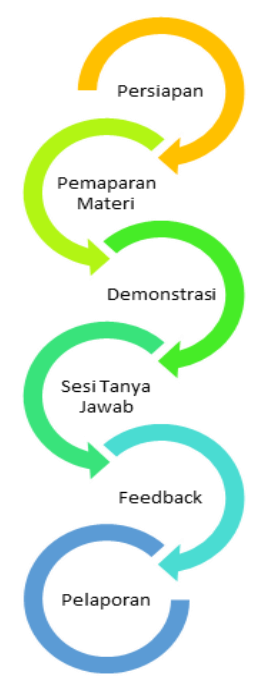

Gambar 2. Metode Pelaksanaan PkM 
Pelatihan ini dimulai dari seluruh panitia melakukan persiapan lalu selanjutnya pelaksanaan terbagi menjadi beberapa sesi yaitu 1) Sesi presentasi, kegiatan ini dilakukan untuk menjelaskan konsep-konsep utama yang akan digunakan dalam melakukan pengembangan website dengan menggunakan framework CodeIgniter, 2) Sesi demonstrasi, kegiatan ini dilakukan untuk memberikan contoh pembuatan yang disertai dengan pemberian model belajar kepada para peserta untuk dapat mengikuti sesi demonstrasi, 3) Sesi tanya jawab, kegiatan ini dilakukan untuk memberikan kesempatan kepada peserta jika ada materi ataupun langkah-langkah yang belum bisa diikuti serta dipahami. 4) Sesi Pengisian Feedback dari peserta, yang akan digunakan sebagai parameter pengukuran kepuasan peserta terhadap kegiatan PkM. Parameter feedback disajikan dalam bentuk angket dengan menggunakan 11 pertanyaan terkait dengan pelatihan yang berikan (Sugiyono, 2016). Adapun pertanyaan pelatihan terdiri dari 1) materi yang disampaikan oleh narasumber, 2) respon peserta terhadap materi yang disampaikan, 3) hubungan materi yang disajikan dengan kebutuhan peserta, 4) keterkaitan antara materi dengan aplikasi yang dapat diserap peserta, 5) keterkaitan antara materi dengan aplikasi yang dapat diserap peserta, 6) keterkaitan materi dengan kebutuhan, 7) pemateri dan teknik penyajian, 8) waktu yang digunakan dalam pemberian materi, 9) kejelasan materi, 10) minat peserta terhadap kegiatan dan 11) Tingkat kepuasan terhadap kegiatan secara keseluruhan. Jawaban dari umpan balik yang diberikan menggunakan skala likert dengan 5 jawaban yang dimulai dari baik sekali, baik, cukup, kurang dan sangat kurang

\section{HASIL DAN PEMBAHASAN}

Pelatihan ini dilakukan oleh 1 orang narasumber utama yang akan menyampaikan materi pelatihan, 1 orang moderator yang akan memandu jalannya pelatihan, dan 3 orang technical support. Kegiatan ini dilaksanakan pada hari Jum'at tanggal 09 Juli 2021 dikediaman masingmasing dengan menggunakan media online yaitu zoom meeting. Selain menggunakan zoom meeting, kegiatan pelatihan ini disiarkan langsung dengan menggunakan Youtube pada channel resmi Universitas Bina Insani yang dapat diakses dengan link https://www.youtube.com/watch?v=M4M8DpEp4cE\&t=372s.

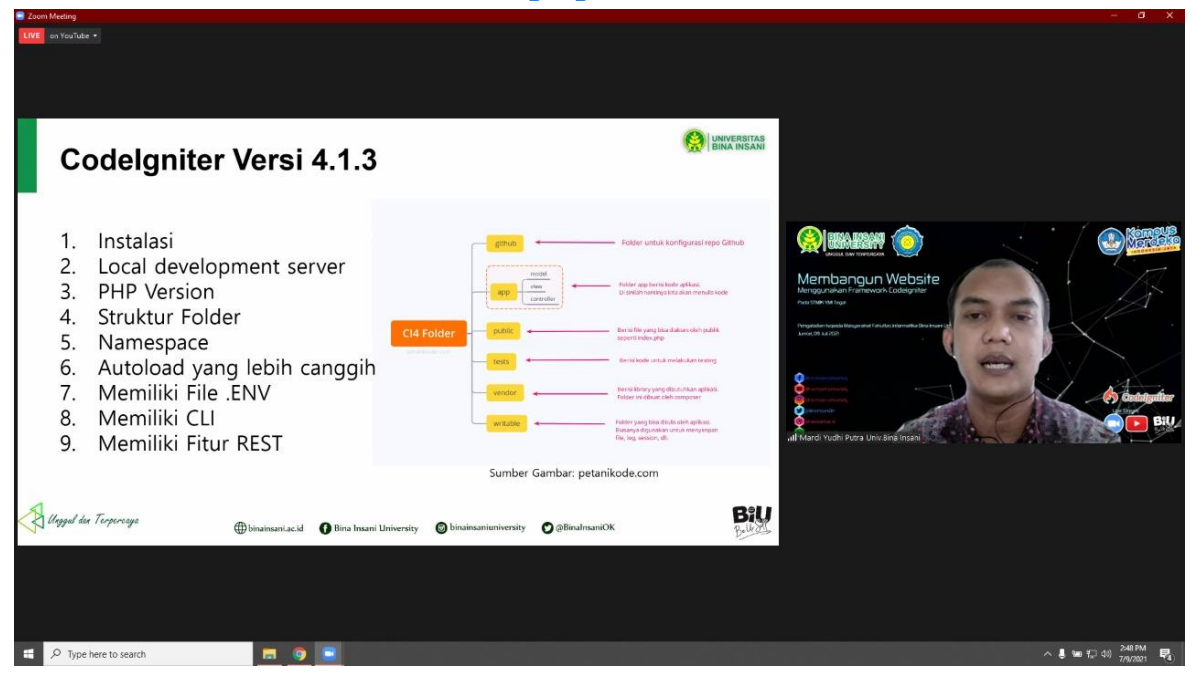

Gambar 2. Kegiatan PkM Pelatihan online melalui Zoom Meeting (Sumber: Hasil Kegiatan Tahun 2021) 
Kegiatan ini juga merupakan bentuk implementasi dari kerjasama yang dilakukan oleh Universitas Bina Insani dengan STMIK YMI Tegal untuk mendukung institusi dalam Akreditasi. Hasil dari pelaksanaan pelatihan ini diharapkan seluruh mahasiswa Program Studi Teknik Informatika dan Sistem Informasi STMIK YMI Tegal dapat memahami dan menerapkan penggunaan codeigniter dalam pembangunan website. Adapun wujud dari pencapaian kegiatan pelatihan ini dapat dilihat dari jumlah peserta dan umpan balik yang diberikan oleh peserta setelah pelaksanaan kegiatan pelatihan ini.

Sebagai salah satu bentuk upaya yang dilakukan pada pelatihan ini, maka kegiatan ini memiliki berpedomana pada prinsip dan indikator pelatihan. Untuk indikator pada pelatihan terdiri dari absesnsi (kehadiran) dan kedisiplinan dari peserta pelatihan (Elfrianto, 2016). Maka dari itu untuk mendapatkan data mengenai absensi peserta, pada pelatihan ini menggunakan media google form. Berdasarkan hasil pengisian daftar hadir tersebut, kegiatan ini bukan hanya diikuti oleh mahasiswa tetapi juga oleh dosen dengan jumlah 85 respon dengan presentase dari 90,6 \% mahasiswa dan 9,4\% dosen.

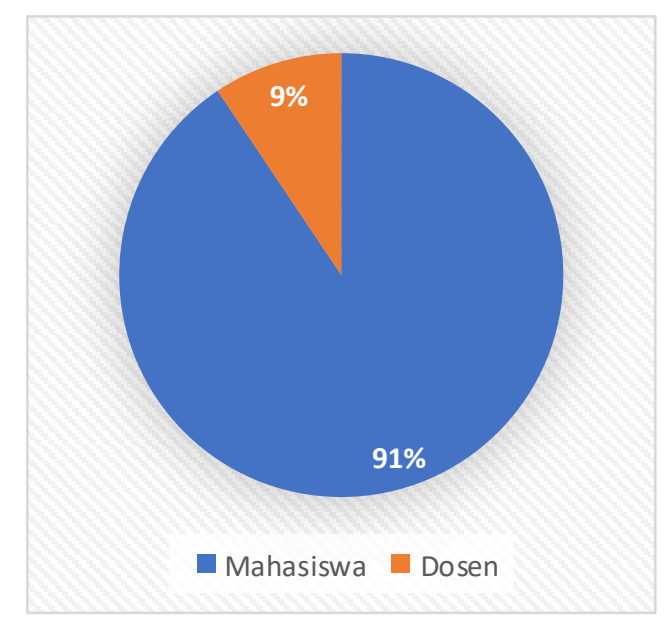

Gambar 3. Presentase Kehadiran Peserta

Capaian dari prinsip pelatihan ini adalah adanya umpan balik, partisipasi, serta relevansi (Elfrianto, 2016). Relevansi pelatihan yang dimaksud adalah kemampuan peserta dalam menguasai dan implementasi materi pelatihan yang diberikan (Mardikanto, 1999). Sedangkan partisipasi yang dimaksud adalah keterlibatan para peserta dalam pelaksanaan pelatihan (Noviyanti \& Setyaningtyas, 2017). Hal tersebut dapat dilihat dari umpan balik yang diberikan oleh para peserta. Umpan balik merupakan bentuk evaluasi yang dapat menggambaran tingkat keberhasilan dari pelatihan selain itu dapat melihat bagaimana relevansi dan partisipasi dari pelatihan (Defi, 2017).

Umpan balik yang diberikan dengan menggunakan google form, dan disajikan dalam bentuk angket dengan menggunakan 11 pertanyaan terkait dengan pelatihan yang berikan (Sugiyono, 2016). Adapun pertanyaan pelatihan terdiri dari 1) materi yang disampaikan oleh narasumber, 2) respon peserta terhadap materi yang disampaikan, 3) hubungan materi yang disajikan dengan kebutuhan peserta, 4) keterkaitan antara materi dengan aplikasi yang dapat diserap peserta, 5) keterkaitan antara materi dengan aplikasi yang dapat diserap peserta, 6) 
keterkaitan materi dengan kebutuhan, 7) pemateri dan teknik penyajian, 8) waktu yang digunakan dalam pemberian materi, 9) kejelasan materi, 10) minat peserta terhadap kegiatan dan 11) Tingkat kepuasan terhadap kegiatan secara keseluruhan. Jawaban dari umpan balik yang diberikan menggunakan skala likert dengan 5 jawaban yang dimulai dari baik sekali, baik, cukup, kurang dan sangat kurang.

Hasil dari umpan balik yang diberikan diperoleh 62 respon yang diberikan dari total 85 peserta, dari perolehan tersebut tercatat $72,9 \%$ peserta memberikan umpan balik dan 27,1 persen tidak memberikan umpan balik dari pelatihan yang telah dilakukan. Respon peserta terhadap materi yang disampaikan oleh narasumber dapat disimpulkan baik sekali, hal ini terlihat dari peraihan $62,9 \%$ respon. Sisanya menyatakan baik dan cukup hal ini menjadi masukan untuk penyelenggara sebagai acuan perbaikan dalam pemberian materi.

Tingkat kepuasan terhadap kegiatan secara keseluruhan dapat dilihat pada gambar 4 . Terdapat 56,5\% yang memberikan respon hal ini menunjukan bahwa tingkat kepuasan peserta terhadap kegiatan sudah sangat baik. Dengan hasil ini dapat disimpulkan kegiatan ini bermanfaat bagi peserta.

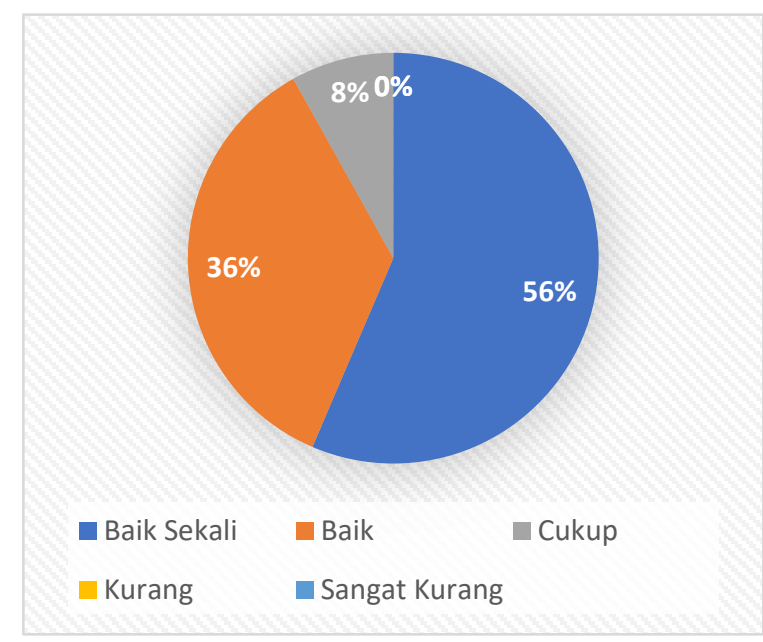

Gambar 4. Persentase Tingkat Kepuasan Peserta

Beberapa masalah yang terjadi ketika pelatihan dilakukan secara online seperti terkendala koneksi baik dari peserta ataupun narasumber, kurangnya komunikasi yang interaktif antara peserta dengan narasumber, serta kurangnya kontrol yang dilakukan oleh narasumber ketika melakukan demo sederhana.

\section{KESIMPULAN}

Berdasarkan dari umpan balik dari peserta, secara keseluruh tingkat kepuasan peserta pelatihan merasa puas dengan pelatihan yang diselenggarakan. Hal ini dapat dilihat dari perolehan respon peserta terhadap pertanyaan mengenai tingkat kepuasan yaitu $56,5 \%$. Namun ada beberapa kendala dan catatan yang dapat diambil untuk perbaikan dalam kegiatan selanjutnya, seperti materi yang disampaikan dengan waktu selama proses pelaksanaan serta kendala konektivitas. Keberlanjutan dari kegiatan ini diharapkan adanya pelatihan dengan tingkat lanjut agar wawasan dan pemahaman mitra tetap terjaga serta dapat sharing knowledge menggunakan jenis framework PHP yang lainnya. 


\section{UCAPAN TERIMA KASIH}

Terima kasih kami ucapkan kepada seluruh pihak yang sudah mendukung pelaksanaan kegiatan PkM pelatihan online Membangun Website dengan Menggunakan Framework Codeigniter pada STMIK YMI Tegal. Selain itu kami ucapkan terima kasih atas kerjasama serta kontribusi dari Ketua STMIK YMI Tegal, Rektor Universitas Bina Insani, Dekan Fakultas Informatika Universitas Bina Insani, Dosen tim PkM Universitas Bina Insani serta tak lupa mahasiswa/i peserta pelatihan.

\section{REFERENCES}

Afuan, L. (2010). Pemanfaatan Framework Codeigniter dalam Pengembangan Sistem Informasi Pendataan Laporan Kerja Praktek Mahasiswa Program Studi Teknik Informatika Unsoed. Juita, 1(2), 39-44.

Defi, W. S. (2017). Faktor Yang Mempengaruhi Efektivitas Pelatihan Di LPK Pacific Marine School Yogyakarta.

Destiningrum, M., \& Adrian, Q. J. (2017). Sistem Informasi Penjadwalan Dokter Berbassis Web Dengan Menggunakan Framework Codeigniter (Studi Kasus: Rumah Sakit Yukum Medical Centre. Jurnal Teknoinfo, 11(2), 30-37. https://doi.org/10.33365/jti.v11i2.24

Elfrianto. (2016). Manajemen Pelatihan Sumber Daya Manusia dalam Meningkatkan Mutu Lulusan. EduTech: Jurnal Ilmu Pendidikan Dan Ilmu Sosial, 2(2), 46-58. https://doi.org/10.30596/edutech.v2i2.596

Mardikanto. (1999). Peningkatan Relevansi Pelatihan Dengan Kesempatan Kerja. Jurnal Ilmu Pendidikan, 6(2). https://doi.org/10.17977/jip.v6i2.2332

Mubarok, R., \& Afifah, N. N. (2020). Artikel Sejarah Web Service.

Noviyanti, A. K., \& Setyaningtyas, E. W. (2017). Partisipasi Pembelajaran Siswa dalam Pembelajaran Dengan Classroom Rules. Journal of Education Research and Evaluation, 1(2), 65. https://doi.org/10.23887/jere.v1i2.10071

Permatasari, I., \& Hardiyan, H. (2018). Pengaruh E-Learning Sebagai Media Pelatihan dan Pengembangan Terhadap Kinerja Karyawan BCA KCU Tangerang. Jurnal Sisfokom (Sistem Informasi Dan Komputer), 7(1), 1-8. https://doi.org/10.32736/sisfokom.v7i1.275

Putra, G. U., \& Mualim, W. (2017). Implementasi Framework MVC Pada Sistem Informasi. Jurnal Spirit, 9(2).

Retnoningsih, E., Solikin, S., Setiyadi, D., \& Pramudita, R. (2020). Pelatihan Online Database Fundamental Untuk Aparatur Sipil Negara dan non Aparatur Sipil Negara Pemerintah Kota Bekasi. Jurnal Pengabdian Kepada Masyarakat UBJ, 3(2), 149-162. https://doi.org/10.31599/jabdimas.v3i2.193

Rosmala, D., Ichwan, M., \& Gandalisha, M. I. (2011). Komparasi Framework Mvc (Codeigniter, Dan Cakephp) Pada Aplikasi Berbasis Web. Jurnal Informatik, 2(8), 22-30.

Sugiyono. (2016). Metode Penelitian Kombinasi (Mixed Methods). Alfabeta.

Surorejo, S., \& Azizah, N. (2015). Sistem Informasi Pengolahan Data Kuesioner Evaluasi Kinerja 
Dosen Pada STMIK YMI Tegal Information System of Processing Lecturers Performance Evaluation Data at STMIK YMI Tegal. Computer Science Research and Its Development Journal, $7(3)$.

Trimarsiah, Y., \& Arafat, M. (2017). Analisis dan Perancangan Website Sebagai Sarana Informasi Pada Lembaga Bahasa Kewirausahaan Dan Komputer AKMI BATURAJA Menggunakan PHP dan MySQL. Jurnal Ilmiah Matrik, 19(1), 1-10. https://doi.org/10.33557/jurnalmatrik.v19i1.366

Tyowati, S., \& Irawan, R. (2017). Implementasi Framework Codeignter Untuk Pengembangan Website Pada Dinas Perkebunan Provinsi Kalimantan Tengah. Jurnal SAINTEKOM, 7(1), 67. https://doi.org/0.33020/saintekom.v7i1.22 